\title{
Proof Power of Authentic Deed Transfer of Land Rights in Legal Perspective of Civil Procedures
}

\author{
Yuda Anrova1 ${ }^{1}$ Eman Suparman², Hazar Kusmayanti ${ }^{3}$ \\ ${ }^{1}$ Faculty of Law, Universitas Padjadjaran, Indonesia \\ yuda160002@mail.unpad.ac.id \\ 2 Faculty of Law, Universitas Padjadjaran, Indonesia \\ eman_professor@yahoo.com \\ 3 Faculty of Law, Universitas Padjadjaran, Indonesia \\ hazar.kusmayanti@unpad.ac.id
}

\begin{abstract}
Introduction to The Problem: Evidence is a process carried out by the parties in resolving disputes to prove the arguments presented before the judge who decides the legal dispute so that the judge can decide as fairly as possible. Evidence under the civil procedure law is regulated in Article 164 HIR. Supreme Court decision number $3591 \mathrm{~K} / \mathrm{Pdt} / 2018$ discusses documentary evidence in the form of an agreement to transfer and transfer land rights and states that the deed has no legal force.

Purpose/Objective Study: The purpose of the study was to determine the legal considerations for the strength of authentic deed evidence in the Supreme Court Decision number 3591K/Pdt/2018, connected with civil procedural law. The research method used is a normative juridical approach to the research specification in descriptive-analytical analysis and qualitative normative.
\end{abstract}

Design/Methodology/Approach: The method used in this research is normative juridical research which focuses on the applicable legal provisions.

Findings: The research results that the authentic deed submitted by the Defendants in the Reconvention as evidence has external and formal evidentiary power. However, authentic deeds that are perfect and binding do not have a coercive or decisive character. Authentic deed evidence can be invalidated if there is evidence of the opponent which can prove otherwise. Based on the decision of the Supreme Court number 3591K/Pdt/2018, the Notarial Deed of the Transfer of Land Rights Agreement has no legal force because land rights have been transferred and building use rights are attached.

Paper Type: Research Article

Keywords: Proof; Land Rights; Authentic Deed; Supreme Court; Civil Law

\section{Introduction}

According to Article 1 paragraph (3) of the 1945 Constitution, Indonesia is a state of law. One of the special characteristics is the existence of an independent and impartial judiciary. The existence of such a judicial institution for resolve disputes for the sake of upholding the positive law (Frebriandini, 2014). The process of settling civil cases through litigation begins with the submission of a lawsuit or application to the Chief 
Justice of the District Court that is adjudicating. This procedure is a general procedure, applies to parties who feel aggrieved and is a civil cases in general (Aulia et al., 2017).

The dispute resolution process is through litigation, so a proof process is needed. Furthermore, Sofyan Muchtar argued that evidentiary is a process of corroborating the arguments of an indictment or lawsuit and the key to winning a case (Mukhtar, 2017). Louis Kaplow said in his research, "Systems of adjudication base outcomes on whether the strength of available evidence and the burden of proof is a central feature of all systems of adjudication" (Kaplow, 2011).

Evidentiary is part of formal law, which aims to maintain material law (Tjukup et al., 2015). The process is carried out by the parties in resolving disputes to prove the arguments presented before the judge who decides the legal dispute so that the judge can decide as fairly as possible. If the panel of judges wishes to put down the truth found in the decision to be passed, that truth must be tested by means and with the strength of every found evidence (Nugroho, 2017).

Expensive and difficult justice for the parties resulted in many decisions filed with cassation until the judicial review in the Supreme Court. The parties argued that their party's proof was more accurate than the other parties. The existence of different views on a case makes the decisions of each level of justice can be different. It is hoped that a judge's decision will be impartial in determining who is right and who is not right in a case and ends the dispute or case (Kusmayanti \& Hawari, 2020). Judges cannot quickly issue a decision without a prior evidentiary process. This process helps the judge to know the certainty of an event that the parties dispute. The stand and independence of judges are urgently needed when they are assigned to burden the parties to prove or order the parties to prove the arguments that have been put forward. The obligation to prove is the duty of the disputing parties. The judges must hear all the parties' evidence because the judge is bound by principles audi et alteram partem.

It is not easy to decide a case to achieve true justice. Law can only be enforced, and justice can only be felt if the examination process before the court is carried out with accuracy and thoroughness to produce a judge's decision that is qualitatively good quality and fulfills the sense of justice of the community. However, there are many problems in order to issue a fair decision for the parties. One of them is the judge's judgment process as the party who decides the case based on evidence. The judge must be able to formulate a decision by looking at the evidence of the parties. If the plaintiff can prove his argument, then the plaintiff wins and vice versa. Civil procedural law evidentiary process is tied to existing evidence and does not require the conviction of a judge. It is different from the evidentiary system in the criminal procedural law that follows negatief wettelijk bewijsleer, or there must be a judge's conviction from the facts (Samudera, 1992). 
Judges at trial are very bound by the evidence presented, and the judge is obliged to decide according to the existing evidence. The judge decides a case based on evidence determined by the civil procedural law. Apart from that, judges also need to assess the evidence made by the parties (Kusmayanti et al., 2019). So that, a decision that upholds justice can be reached. Evidence in civil procedural law is regulated by Article 1866 of the Civil Code (KUH Perdata) and Article 164 Herzien Inlandsch Reglement (HIR).

For example, the Supreme Court Decision number 3591K/Pdt/2018. In its consideration, the panel of judges shall provide a separate assessment of the evidence presented by the parties. The judges gave a verdict without giving clear legal considerations in advance in the reconstruction lawsuit, so the authors took decision number $3591 \mathrm{~K} / \mathrm{Pdt} / 2018$ as the object of the paper. In that case, PT. DAM Utama Sakti and Fandam Darmawan as Directors of PT. DAM Utama Sakti sued the heirs of Jajat Samsudajat regarding the agreement of transfer of land rights. PT. DAM Utama Sakti asked for a deed of agreement on the transfer of land rights to be declared invalid and without legal force because of PT. DAM Utama Sakti already has a building rights certificate for a plot of land in the Ciumbuleuit area (land object of dispute). After submitting the lawsuit, the agenda for the next trial is that the parties are welcomed to be able to prove their respective arguments. The parties then perform evidence that is useful to prove the arguments put forward by submitting evidence to prove their rights.

According to Lawrence Crocker, to apply the burden of proof for the parties must pay attention to the following provisions; burdens can be thought of as four-place predicates. The first is who bears the burden; the second is what or how heavy the burden is; the third is the effect of failing to carry the burden; the fourth is succeeding in carrying it (Crocker, 2008). Based on this case, the judges have different judgments on the evidence made by these parties.

Based on the views and legal considerations of the judges at the Bandung District Court, PT. DAM Utama Sakti was accepted. The Bandung District Court believes that the agreement deed cannot be declared invalid because it has been made before a notary. However, the agreement deed has no legal force. The heir of the late Jajat Samsudajat then submitted an appeal to the Bandung High Court with a memory of appeal that essentially rejected the Bandung District Court's decision. The heirs are of the opinion that PT. DAM Utama Sakti has committed a tort. Jajat Samsudajat's heir believes that PT. DAM Utama Sakti was unable to prove its rebuttal arguments regarding the application for the issuance of building rights against the law so that the heirs should be won. The Panel of High Court Judges then granted the appeal submitted by the beneficiary. The Panel of Judges decided that PT. DAM Utama Sakti has conducted tort regarding the issuance of building rights certificates. 
Based on their considerations, the panel of judges was of the opinion that the proof of the agreement deed was still declared valid and legally binding so that PT. DAM Utama Sakti that issued the building rights without paying the compensation money in advance for the transfer of land rights in 1997 is a tort. PT. DAM Utama Sakti and Fandam Darmawan then submitted an appeal to the Supreme Court. The Supreme Court's petition for cassation was granted with the injunction that the Supreme Court canceled the High Court's decision and stated that PT. DAM Utama Sakti and Fandam Darmawan did not conduct tort. Based on this case, it can be seen that the evidence made by the parties has a different value before each judge. It can lead to the absence of legal certainty related to the parties' evidentiary proof, evidentiary procedure, and evidence position as the basis for judges' decisions.

The decision above has a problem of differences in the judges' assessment of evidence regarding the validity and the position of the authentic deed. The author feels that there is a shortage of judges seeing the evidence made by the parties. Therefore, the author will examine more deeply the evidentiary process in the Supreme Court decision number $3591 \mathrm{~K} / \mathrm{Pdt} / 2018$ in order to find a way out for the assessment of proof of civil cases in terms of Civil Procedural Law.

\section{Methodology}

This research uses normative juridical research, which focuses on the applicable legal provisions, namely the Civil Code, Law No. 48 of 2009 concerning Judicial Power, the Het Herziene Indonesisch Reglement or HIR, and the Law on the Position of Notary. This research specification is descriptive-analytical then analyzed using qualitative methods. This research was conducted by means of library research to obtain secondary data using legal materials (primary), secondary legal materials, and tertiary legal materials.

\section{Results and Discussion}

\section{Legal Theory and Legal Issues Related to the Proof Power of Authentics Deeds}

Civil procedural law is a formal law used to enforce civil law as material law (Ardiansyah, 2020). The civil law enforcement process is carried out by means of an evidentiary process. Proof of a civil case is crucial in civil procedural law. Evidentiary in the civil court process is a formal search for truth. This evidentiary process makes civil procedural law different from criminal procedural law. The provisions of the various kinds of evidence are used as a guide by the judge in assessing the evidence (Prasetyo et al., 2018). The order of evidence in civil procedural law which places letter evidence in the first order, means that documentary evidence is the highest evidence in civil procedural law (Palit, 2015). A matter that does not include reading marks or includes reading marks but the contents cannot be understood is not included in a letter or written evidence (Makarao, 2009).

In practice, there are often problems with documentary evidence. One of them is the case that the author will discuss, namely the Supreme Court Decision Number 
3591K/Pdt/2018. There is evidence of a letter in the form of an agreement on the transfer of land rights. Basically, the evidentiary system is the arrangement of the kinds of evidence that may be used, the decomposition of the evidence, and in what ways the evidence is used and in what way the judge must form his conviction (Rozi, 2018). In that case, PT. DAM Utama Sakti and Fandam Darmawan as Director of PT. DAM Utama Sakti sued Jajat Samsudajat's heirs regarding the transfer of land rights agreement.

PT. DAM Utama Sakti asked for the deed of agreement to transfer land rights, which was declared invalid and had no legal force because of PT. DAM Utama Sakti already has a building rights certificate for a plot of land in the Ciumbuleuit area (the object of dispute). After submitting the lawsuit, the agenda for the next trial is for the parties to prove their respective arguments. The parties then carry out useful evidence to prove the arguments put forward by submitting evidence to prove their rights. Based on this case, the judge has a different assessment of the evidence made by the parties. As we know Indonesia's civil regulation has maintain how to proof an evidence for the court. Letter or writing evidence has the best function as evidence in Indonesia's civil law procedure. The legal rules regarding written or letter evidence can be found in Articles 138, 165-167 HIR / 164, 285 - 305 RBg. A letter is anything that contains reading signs and contains thought in handwritten, typed, or printed form (Siahaan, 2019).

Based on the judge's view at the Bandung District Court, the lawsuit of PT. DAM Utama Sakti accepted. The Bandung District Court is of the opinion that the deed of agreement cannot be declared invalid because it has been made before a notary. So the deed of agreement has legal force, rights or laws cannot be realized, and has executive power (to be implemented) (Ekasari, 2019).

Based on the Supreme Court Decision Number 3591K/Pdt/2018, there was a dispute regarding land rights between PT DAM Utama Sakti (Plaintiff in the Reconvention), who filed a lawsuit against Almarhum Jajat Samsudajat's wife and children (Defendant in the Reconvention) regarding land rights agreements. In 1993, the Plaintiff in the Reconvention entered into an agreement to transfer land rights with Jajat Samsudajat (Husband of the Defendants in the Reconvention). The agreement was made by and in the presence of Tien Norman Lubis, S.H. Notary in Bandung. In 2004, the Plaintiff in the Reconvention received a building rights certificate for the land object of the dispute after submitting an application for building rights over the land to the National Land Agency.

The problem arose when in 2016, the wife and children of the late Jajat Samsudajat filed a lawsuit of tort with register number 347/Pdt.G/2016/PN.Bdg against PT. DAM Utama Sakti and Fandam Darmawan. Alamarhum Jajat Samsudajat's wife and children consider the issuance of building rights on the land of the object of the dispute is not in accordance with good procedures because the Plaintiff in the 


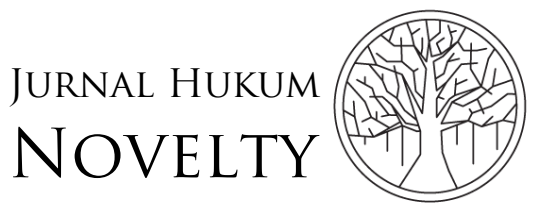

Volume 12, Issue 02, 2021, pp. 237-247

Reconvention has not fulfilled its obligations in the agreement to hand over and transfer the land rights. During the answering process, PT. DAM Utama Sakti (Plaintiff I in Reconvention) and Fandam Darmawan (Plaintiff II in Reconvention) sent a lawsuit to Jajat Samsudajat's wife and children (the Defendants in the Reconvention) regarding the agreement to transfer and transfer the rights to the land.

Based on the evidentiary process at trial, the Defendant in the Reconvention submitted an authentic deed in the form of an agreement to transfer and hand over land number 255 as evidence to the judge. Defendant in the Reconvention feels that the land object of the dispute is still the right of the Defendant in the Reconvention. The evidence of the agreement contains the rights and obligations of the parties in the agreement. Civil procedural law places documentary evidence as to the first evidence because letters in civil society are often made deliberately to serve as evidence if there is a dispute in the future.

Legal considerations by the panel of judges at the Supreme Court stated that they did not reject the evidence. However, the panel of judges stated that rights to cultivated land could not be equated with property rights. The panel of judges considered that changing the status of a cultivator to becoming a land owner must go through a land administration process to the National Land Agency. According to the panel of judges, the cultivator only had the status of cultivator of the land he was cultivating and not as the owner of the land he was cultivating. Therefore, the Defendant in the Reconvention was declared unable to prove the arguments presented with the evidence of the agreement deed. The panel of judges is of the opinion that the Plaintiff in the Reconvention can prove himself as the party entitled to the disputed land.

According to the theory of the expert, the evidentiary power of authentic deeds can be divided into 3 (three) parts (Harahap, 2005):

1. Strength of External Evidence

An authentic deed must be considered and treated as an authentic deed unless it can be proven otherwise. It can be called a principle acta publica sese ipsa (Mertokusumo, 2011). If it can be proven that the authentic deed is fake, then the authentic deed cannot be assessed and accepted as an authentic deed.

\section{Strength of Formal Evidence}

The strength of formal proof on authentic deeds is explained in Article 1871 of the Civil Code, that everything contained in it is a truth given and conveyed by the signatory to the official who made it. Everything that the official explains in the deed is acknowledged to be true.

\section{The Power of Material Evidence}

The strength of material proof of authentic deeds concerns the main content of the deeds. The validity and correctness of the contents of the authentic deed is a matter that the judge assesses. In general, official deeds have no material evidentiary power. 
Deeds that have material proof power are deeds issued by the Civil Registration Office.

If associated with the Supreme Court decision Number 3591K/Pdt/2018, the authentic deed submitted by Defendant in the Reconvention has 2 (two) powers of proof. Evidence as external evidence and the power of formal proof (Kobis, 2017). The authentic deed of the agreement of transfer and handover of land rights submitted by the Defendant in the Reconvention in the trial has the power of proof as external evidence. The authentic deed submitted by the Defendant in the Reconvention as evidence must be accepted as authentic. The judge cannot rule out the validity of the authentic deed when it is submitted as evidence but does not rule out the possibility that the strength of external evidence may be lost if the opposing party can prove the deed's falsity (Kaplow, 2011).

\section{Implementation and Regulation the Proof Power of Authentic Deed in the Decision Number 3591K/Pdt/2018}

The authentic deed of the agreement of transfer of land rights submitted by the Defendant in the Reconvention in the trial has formal evidentiary power. All information contained in the authentic deed can be justified as information conveyed and given by the parties to the authorized public official, in this case a Notary Public (Din, 2019). The deed drawn up before the Notary is in accordance with the provisions of laws and regulations as it is one of several other notary authorities (Sajadi et al., 2015). Notaries have the authority to make authentic deeds, guarantee the certainty of the date of making the deed, keep the deed, provide grosses, copies and excerpts of the deed, validate signatures, record letters under hand, make copies of original letters under hand, validate photocopies compatibility, provide information on making deeds, make a deed of trial minutes, and other authorities determined by law. The deed made by the notary describes authentically all the stipulations, agreements, and actions witnessed by the parties and witnesses. An authentic deed contains an agreement between the parties who appear before a notary public (Irawan et al., 2018). This is done to realize the right of citizens to legal certainty and justice (Iryadi, 2019).

Refer to Articles 165 of the HIR and 1870 of the Civil Code, the status of the authentic deed is perfect (volledig) and binding (bindende). The truth of the authentic deed cannot be denied unless it can be proven otherwise, for example, there is falsification in the deed. It can assist judges in deciding cases without any doubt (Juanda, 2016). The judge must trust the status of authentic deeds as evidence, but authentic deeds do not have the character of determining (besslissend) or compelling (dwigende).

Based on the case in the Supreme Court Decision Number 3591K/Pdt/2018, the authentic deed used is the authentic deed made by the parties before Tien Norman Lubis, S.H. Notary in Bandung. An authentic deed in a case is in the form of a partijakte deed, meaning a deed involving two parties. Based on the case, the party to the 


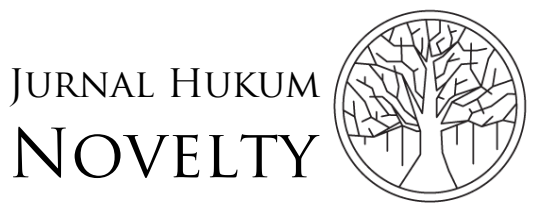

Volume 12, Issue 02, 2021, pp. 237-247

P-ISSN: 1412-6834

E-ISSN: 2550-0090

agreement deed was PT. DAM Utama Sakti and Jajat Samsudajat. Cancellation of deeds requires clear reasons and is requested from the judge. The judge ex officio cannot cancel the agreement if the judge has never asked for cancellation. Cancellation can only be requested if there is evidence that the opponent is filed because even though the authentic deed is binding and perfect, the authentic deed is not coercive or decisive. According to the law, compelling evidence is evidence that cannot be denied, disabled, or set aside with evidence of the opponent.

The Supreme Court Decision Number 3591K/Pdt/2018 states that the deed of transfer of rights to land carried out by the Plaintiff in the Reconvention and Defendant in the Reconvention has no legal force. The judge was of the opinion that the position of the agreement deed was accepted as evidence, and the power of proof of the deed was still attached to the authentic deed. The judge was of the view that the evidence of the opponent denied the submission of the agreement deed as evidence in a case. The counter-evidence in question is evidence submitted by Plaintiff in the Reconvention in the form of a building rights certificate. The judge's consideration stated that the authentic deed of transfer of land rights carried out by the Cultivator to the Plaintiff in the Reconvention could not grant land rights to the Defendant in the Reconvention of the said land.

The Supreme Court stated that the legal consideration of the Judex Facti (District Court and High Court) decision had wrongly applied the law. The Notary Deed of the transfer of working rights cannot win against the evidence against the building rights certificate in the name of the Plaintiff in the Reconvention. The Supreme Judge explained that the period of time the Plaintiff in the Reconvention controlled the object of the dispute based on the 2004 building rights certificate was valid and did not violate the rules. It is in accordance with the provisions of Article 32 paragraph (2) Government Regulation number 24 of 1997 concerning Land Registration which states that a person cannot claim his right to a land that has been issued a certificate after a period of 5 (five) years after the issuance of the right. Finally, the Supreme Court stated that the land object of the case was the right of the Plaintiff in the Reconvention, the Defendant in the Reconvention was charged the court fee for all costs from the first trial level, and the agreement deed was declared to have no legal force.

Based on this analysis, the decision of the Supreme Court number 3591K/Pdt/2018, which states that the agreement deeds of the parties are not legally binding have a clear legal basis. The judge's decision will approach justice if taken through a legal interpretation process (Kusmayanti \& Dharmawan, 2020). The judge was of the opinion that the deed had no legal force because of the opposing evidence, which stated that the Defendant in the Reconvention had the right to the disputed land. The Supreme Court's decision shows the evidentiary power of authentic deed evidence, which is the strongest evidence in accordance with Article 164 HIR. The Panel of Judges has based its decision on the applicable positive law regarding the strength of 
proof and the position of the authentic deed, which is perfect and binding but does not necessarily make the authentic deed as compelling and decisive evidence.

\section{Conclusion}

Based on the description of the discussion in the previous description, the author can conclude that letter evidence is placed as the strongest evidence in civil procedural law. Supreme Court verdict was that the deed had no legal force because of the opposing evidence that the Defendant in the Reconvention had the right to the disputed land. The authentic deed submitted by Ristiane Hardayun Putri and Ratu Ayu Ardita Lestari (The Defendants in the Reconvention) as evidence has external and formal evidentiary power. However, authentic deeds that are perfect and binding do not have a coercive or decisive character. Authentic deed evidence can be invalidated if there is evidence of the opponent which can prove otherwise. Based on the decision of the Supreme Court number 3591K/Pdt/2018, the agreement deed has no legal force because land rights have been transferred and building Use Rights are attached.

\section{Acknowledgment}

The authors would like to say thank you to Universitas Ahmad Dahlan for the acceptance of our research. We would like to say thank you to Universitas Padjadjaran for the support of the author's research. Sincere gratitude also goes to anonymous reviewers and editors who have provided constructive feedback so that this manuscript looks worth reading and citing.

\section{Declarations}

Author contribution : Author 1: make a data collection, revised the research idea, and searching the decision; Author 2: make a draft writing, review literature, initiated the research ideas, and made an analysis; Author 3: suggest the other author and review the final writing.

Funding statement : This research is funded by the author.

Conflict of interest : The authors declare no conflict of interest.

Additional information : No additional information is available for this paper.

\section{References}

Ardiansyah, M. K. (2020). Pembaruan Hukum oleh Mahkamah Agung dalam Mengisi Kekosongan Hukum Acara Perdata di Indonesia. Jurnal Ilmiah Kebijakan Hukum, 14(2), 361-384. https://doi.org/10.30641/kebijakan.2020.V14.361-384

Aulia, N. J., Hanifah, M., \& Hendra, R. (2017). Eksekusi Riil Terhadap Putusan Hakim yang Telah Mempunyai Kekuatan Hukum Tetap pada Perkara Perdata No.20/P.dt.G/2011/PN.Pbr di Pengadilan Negeri Kelas IA Pekanbaru. Jurnal Online Mahasiswa (JOM) Bidang Ilmu Hukum, 3(2), 1-15. https://jom.unri.ac.id/index.php/JOMFHUKUM/article/view/15461

Crocker, L. (2008). Ethics and the Law's Burdens of Proof. Philosophical Issues, 18(1), 272-293. https://doi.org/10.1111/J.1533-6077.2008.00148.X 
Din, T. (2019). Pertanggungjawaban Notaris terhadap Akta Otentik Terindikasi Tindak Pidana. Jurnal Penelitian Hukum De Jure, 19(2), 171. https://doi.org/10.30641/dejure.2019.V19.171-183

Ekasari, L. P. H. (2019). Kekuatan Putusan Pengadilan Tata Usaha Negara yang Berkekuatan Hukum Tetap Terhadap Pembatalan Sertifikat Hak Milik Atas Tanah Melalui Kewenangan Kepala Kantor Pertanahan. Jurnal Hukum Prasada, 6(1), 22-35. https://doi.org/https://doi.org/10.22225/jhp.6.1.1006.22-35

Frebriandini, T. S. (2014). Studi Kekuatan Pembuktian Surat Pada Sengketa Perdata Di Pengadilan Negeri | Frebriandini | Verstek. Jurnal Verstek, 2(1), 176-187. https://jurnal.uns.ac.id/verstek/article/view/38848

Harahap, M. Y. (2005). Hukum Acara Perdata tentang Gugatan Persidangan Penyitaan Pembuktian dan Putusan Pengadilan. Sinar Grafika.

Irawan, A. A., Budiono, A. R., \& Wijayanti, H. (2018). Pertanggungjawaban Ahli Waris Notaris sebagai Pejabat Umum atas Akta Notaris yang Menimbulkan Kerugian Para Pihak. Lentera Hukum, 5(2), 322-338. https://doi.org/10.19184/ejlh.v5i2.6992

Iryadi, I. (2019). Kedudukan Akta Otentik dalam Hubungannya dengan Hak Konstitusional Warga Negara. Jurnal Konstitusi, 15(4), 796-815. https://doi.org/10.31078/jk1546

Juanda, E. (2016). Kekuatan Alat Bukti dalam Perkara Perdata Menurut Hukum Positif Indonesia. Jurnal Ilmiah Galuh Justisi, 4(1), 27-46. https://doi.org/10.25157/jigj.v4i1.409

Kaplow, L. (2011). Burden of Proof. SSRN Electronic Journal. https://doi.org/10.2139/ssrn.1954006

Kobis, F. (2017). Kekuatan Pembuktian Surat Menurut Hukum Acara Perdata. Lex Crimen, 6(5), 105-113.

Kusmayanti, H., \& Dharmawan, L. (2020). Deed of Settlement as A Dispute Object based on HIR and Supreme Court Regulation No. 1/2016. Jurnal Hukum Novelty, 11(2), 141-151. https://doi.org/10.26555/novelty.v11i2.a16092

Kusmayanti, H., \& Hawari, S. Y. (2020). Praktik Eksekusi Riil Tanah Milik Masyarakat Adat Sunda Wiwitan. SASI, 26(3), 341-355. https://doi.org/10.47268/sasi.v26i3.285

Kusmayanti, H., Putri, S. A., \& Rahmainy, L. (2019). Praktik Penyelesaian Sengketa di Pengadilan Agama Melalui Sidang Keliling Dikaitkan dengan Prinsip dan Asas Hukum Acara Perdata. ADHAPER: Jurnal Hukum Acara Perdata, 4(2), 145-161. https://doi.org/10.36913/jhaper.v4i2.83

Makarao, M. T. (2009). Pokok Pokok Hukum Acara Perdata. Rineka Cipta.

Mukhtar, S. (2017). Penelitian Hukum Acara Perdata Putusan Hakim dan Persepsi Keadilan. Jurnal Hukum \& Pembangunan, 18(1), 39. https://doi.org/10.21143/jhp.vol18.no1.1244

Nugroho, B. (2017). Peranan Alat Bukti Dalam Perkara Pidana Dalam Putusan Hakim Menurut Kuhap. Yuridika, 32(1), 17-36. https://doi.org/10.20473/ydk.v32i1.4780 
Palit, R. C. (2015). Kekuatan Akta di Bawah Tangan Sebagai Alat Bukti di Pengadilan. LEX PRIVATUM, 3(2), 137-145.

Prasetyo, E. S., Ohoiwutun, Y. A. T., \& Halif, H. (2018). Implikasi Yuridis Kebijakan Formulasi Alat Bukti Elektronik. Lentera Hukum, 5(2), 174-193. https://doi.org/10.19184/ejlh.v5i2.7469

Rozi, F. (2018). Sistem Pembuktian dalam Proses Persidangan pada Perkara Tindak Pidana. Jurnal Yuridis Unaja, 1(2), 19-33. https://doi.org/10.35141/JYU.V1I2.486

Sajadi, I., Saptanti, N., \& Supanto, S. (2015). Tanggung Jawab Notaris terhadap Keabsahan Akta Notaris yang Dibuatnya Atas Penghadap yang Tidak Dapat Membaca dan Menulis. Repertorium, 2(2).

Samudera, T. (1992). Hukum Pembuktian dalam Acara Perdata. Alumni.

Siahaan, K. (2019). Kedudukan Hukum Akta Notaris Sebagai Alat Bukti Pada Tindak Pidana Pemalsuan Surat Dalam Proses Peradilan Pidana. Recital Review, 1(2), 72-88.

Tjukup, I. K., Martiana, N. A., Putra, D. N. R. A., Dananjaya, N. S., \& Putra, I. P. R. A. (2015). Penerapan Teori Hukum Pembangunan dalam Mewujudkan Peradilan Sederhana, Cepat dan Biaya Murah. ADHAPER: Jurnal Hukum Acara Perdata, 1(1), 146-160. https://doi.org/10.36913/JHAPER.V1I1.8 